\title{
Assessment of Indigenous Knowledge in Managing Environmental Challenges: A Case Study of Ringim Local Government Area of Jigawa State, Nigeria
}

\author{
Nura Mustapha Mairiga1, Muhammad Ibrahim1,2*
}

${ }^{1}$ Department of Environmental Management and Toxicology, Federal University Dutse, 720101, Jigawa State, Nigeria

${ }^{2}$ College of Environment, Hohai University, Nanjing, 210098, P. R. China

E-mail: nuramustapha57@gmail.com; muhdibrahimnguru@gmail.com

*Corresponding author details: Muhammad Ibrahim; Phone:+8613813825575; muhdibrahimnguru@gmail.com

\begin{abstract}
In many parts of the world, the use of indigenous knowledge to curb the problems of environment and natural resources mismanagement has been effectively applied. This study focused on assessing the efficiency of Indigenous Knowledge in managing the environment and natural resources in Ringim Local Government Area (LGA) of Jigawa State, Nigeria. The study was qualitative consisted of focus group discussion and interviews. The eight discussants' groups defined by ages $(25-40,40-60$, and 60 years old and above) were interviewed on environmental issues and level of indigenous Knowledge. The results revealed that the level of environmental awareness within Ringim community is significantly effective in the management of environment. Also, the efficiency of indigenous knowledge in environmental management was very effective as declared by more than $71 \%$ of the respondents. This indicates that the study area utilizes local knowledge in the management and conservation of their immediate resources and environment. More than $72.92 \%$ of the residents of these communities have blamed the poor drainage network as the major cause of flooding in the area. Therefore, it can be summed up that, the level of environmental awareness, indigenous knowledge in environmental management is very effective within the study area. It was recommended that government and private organizations should collaborate with communities in solving numerous environmental challenges through the application of indigenous knowledge and environmental awareness.
\end{abstract}

Keywords: Indigenous Knowledge (IK); Environmental Management; Ringim; Environmental education

\section{INTRODUCTION}

Over the past centuries, indigenous societies have enormously used the inherited knowledge of their communities and surroundings in managing environmental phenomena such as water, land, forest and other natural resources. The problem of environmental pollution is greatly reduced with enhancement and implementation of environmental policies and regulations [1]. The system of Indigenous knowledge is referred to as a body of knowledge and benefits built by a group of people and handed over to generations upon generations [2]. In many countries, cultural taboos put restrictions on the use of plants, animals or places and this helps to curb the depletion of natural resources that are considered important for the continuation of an important ecosystem. According to Chiwandamira, (2000), due to the fact that there is a strong bond and mutual relationship between the indigenous people and their environment, the need for continuous environmental education from one generation to another is necessary [3]. This tremendously helps local societies in knowing and accepting the advantages and benefits of conserving natural resources within and around them. United States Environmental Protection Agency (EPA) defines the term "Environmental Education" as a process that allows an individual to explore environmental issues, engage in problem solving and take action to improve the environment [4].

In Northern Nigeria, the semi-arid zones face manifold natural hazards but the major ones are drought and flood. These invariably cause famine, food insecurity as well as an abject poverty. However, the communities may have a variety of devised measures in growing drought-resistant and early-maturing indigenous crop varieties, gathering wild fruits and vegetables, and wetlands cultivation which can enable them to survive climatic hazards with little or no support from the outside world. Some communities use local methods in predicting the disasters that could face them and, in most cases, have the knowledge and administrative structures to cope with them, because the communities know that a wellconserved environment helped them reduce risks associated with natural disasters $[5,6]$.

However, this study spatially covers Ringim town, in Ringim local government area of Jigawa state, Nigeria. Natural resources such as vegetation cover, land, and water 
are increasingly exploited in the study area, resulting in disasters such as heavy wind, drought, desert encroachment and flooding (which annually destroys lives and properties). These impacts and associated risks might exist as a result of insufficient environmental awareness.

Therefore, considering the number of environmental catastrophes hitting the study area, this research focused on how the application of indigenous knowledge can be effective in solving environmental issues such as flooding conservation of natural resources, sanitation and waste management. It also looked at the attitude of people towards environment, and examined to see if there would be any variation between the present and old way of managing environment.

\section{RESEARCH METHODOLOGY}

\section{Research Design}

The research adopted a qualitative method of data collection, due to its feature in allowing a researcher to conduct a systematic inquiry and transform into meanings. And it could also be used to gather facts about local people's experiences, beliefs, feelings in certain professions, activities, services offered and so on. In this study, the questionnaires were designed in such a way that participants have chance and freedom to express their thoughts, experiences and perceptions.

\section{Description of the Study Area}

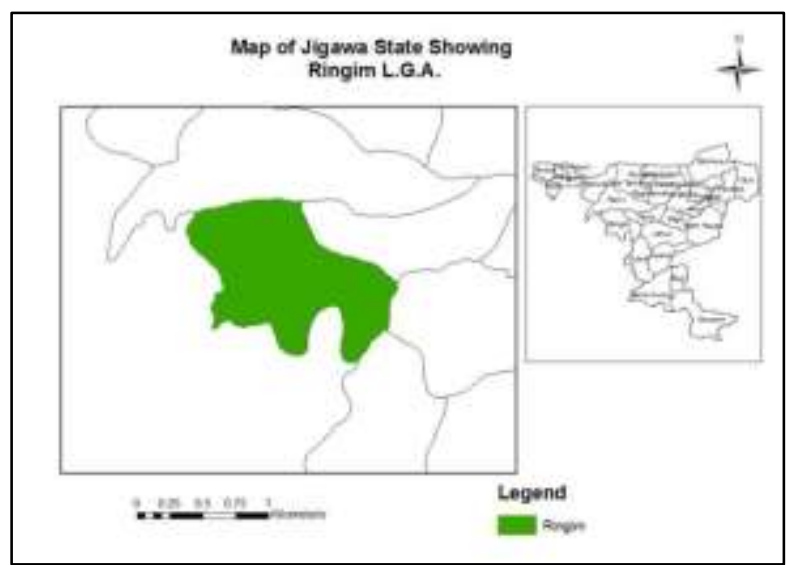

FIGURE 1: Map of Jigawa State Showing Ringim L.G.A. (Source; Arc Map June, 2017)

Ringim is a Local Government Area of Jigawa State, Nigeria. With coordinates of $12^{\circ} 17^{\prime} \mathrm{N} 9^{\circ} 28^{\prime} \mathrm{E}$ and $12.283^{\circ} \mathrm{N} 9.467^{\circ} \mathrm{E}$. Its headquarters located in the historical town of Ringim, the LGA has an area of $1,057 \mathrm{~km}^{2}$ and a projected population of $257,100[7,8]$.

\section{The Brief History of the Study Area}

Ringim emirate came into being in November, 1991 as a result of the creation of Jigawa state from Kano state on 27 August 1991. The emirate consists of four Local Government Areas which includes; Ringim LGA, Taura LGA, Garki LGA and Babura LGA.

\section{Economic Development}

Historically, Ringim LGA was known for its economic development. The area has a fertile land for both wet and dry season farming activities. The Local Government produces both subsistence and cash crops, and also has great number of fruit trees dispersed along the riverine areas. In addition to the farming activities, majority of the populace, engaged in marketing. These economic resources enable most of the households to cater for their daily needs.
The town was famous for its rich in groundnuts, tobacco production and trade. For this reason, the then British colonial masters constructed a railway en route from Kano to Nguru passing via the town.

\section{Educational Development}

Ringim, like many other towns in Northern Nigeria had adopted bi-educational system viz; Islamic and western education. Historically, the year 1930 was the beginning of western educational developments in Ringim. In this year, Katutu Primary School, the first elementary school was established. In 1954, Sabon Gida Senior Primary School was also established. With the provision of Universal Primary Education (UPE) program in 1976 more schools were introduced and student-enrolment drastically increased. In 1976, the first Government Secondary School was formally moved to the town from Dawakin Tofa area of Kano State.

However, with the introduction of the 6-3-3-4 system of education in Nigeria, the students are expected to undergo elementary Schools, Junior and Senior High Schools, and then colleges and universities.

\section{Sampling Technique and Method of Data Collection}

In this study, a stratified random sampling technique was employed in order to enhance the reliability of the study. And a simple approach was also applied so that the actual response of the respondents could be reflected in the analysis. Informal interviews and focus group discussion targeting eight (8) groups defined by ages ( $25-40$ years, 40 - 60 years, and 60 years old and above) were conducted. The groups consisted of both genders of male and female, and the research collected information from the focal and sensitive areas such as homes, market places, village squares and so on. Structured questionnaire was used as a guide during group discussion and interview which covered related questions on environmental education and awareness, and effectiveness of indigenous knowledge within the scope of the study area. The research required the assistance of indigenous resource persons who served as research assistants. This gives a tranquil opportunity to respondents to express their diverse opinions easily.

\section{Data Analysis}

Descriptive Statistics was used to analyze the obtained quantitative data, where a simple percentage analysis was conducted, and the obtained results were presented in tables and bar charts. The information of respondents was divided into two (2) sections viz: Section A, which is the basic information that describes the personal biodata of the respondents, and Section $\mathrm{B}$, which gives more emphasis on the main objective of the study. The latter section conveyed information about the environmental challenges as well as evaluation of the level of indigenous knowledge in the study area.

\section{RESULT AND DISCUSSION}

\section{SECTION A: Biodata of the Respondents}

This section determines the demographic features of the respondents. Percentage distribution tables were used to summarize the biodata of the local respondents in terms of gender and occupation. Table 1 below gives the summary of the findings.

\section{Gender Distribution}

The Table 1 below shows the gender distribution of the respondents 
TABLE 1: Gender Distribution

\begin{tabular}{|c|c|}
\hline GENDER & PERCENTAGE \\
\hline Male & $73.96 \%$ \\
\hline Female & $26.04 \%$ \\
\hline Total & $100 \%$ \\
\hline
\end{tabular}

\section{Occupational Distribution}

The Table 2 below shows the occupational distribution of the respondents

TABLE 2: Occupational Distribution

\begin{tabular}{|c|c|}
\hline OCCUPATION & PERCENTAGE \\
\hline Student & $31.25 \%$ \\
\hline Civil servant & $10.42 \%$ \\
\hline Farmers & $46.88 \%$ \\
\hline Others & $11.46 \%$ \\
\hline
\end{tabular}

\section{SECTION B: Questionnaire Findings}

\section{Environmental Awareness}

Participants were asked on different aspect of environmental awareness ranging from the quality of water effect of pesticide, changes in the weather pattern, construction of sock away near boreholes, stock overgrazing, and air quality. The response was grouped in to three components which includes; Aware, Unaware and Unsure.

As depicted in Figure 2, fifty-seven percent (57\%) of the respondents have declared that they are aware of the environmental problems and some of the adaptive solutions through which they try to make balance between environment and their day-to-day activities. The natural environment and resources are under serious threat and at least cultural taboos and their sanctions have helped to check the abuse of the environment at least among the local people [9].

However, twenty-nine percent (29\%) of the respondents have said to be unaware of environmental issues within their local communities. This percentage is relatively higher and it has shown that there is still need to strengthen the approaches of enlightenment programmes on environmental management in the study area.

In the last category with fourteen percent $(14 \%)$, the respondents have declared their uncertainties about the overall environmental awareness.

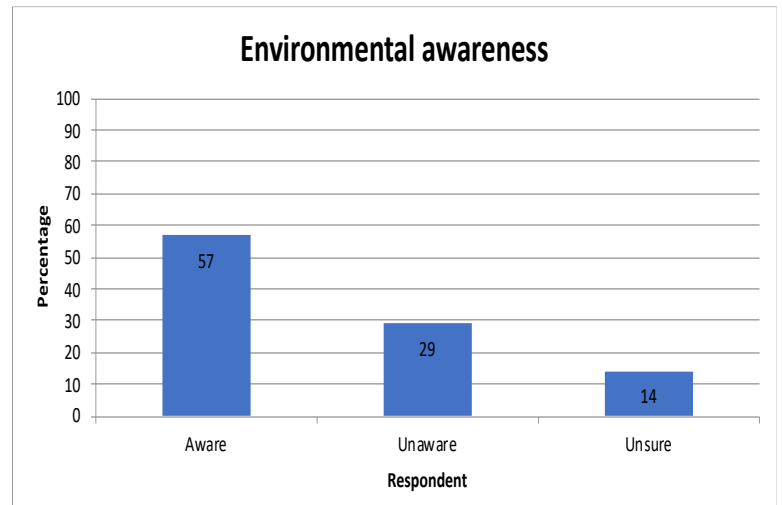

FIGURE 2: Environmental Awareness

As seen above, the results indicated that the level of environmental awareness in Ringim community is significantly effective in the management of environmental challenges.
Attitude Toward Environmental Management

Further questions were asked to justify the results obtained from the previous section. The participants were asked about their attitudes toward developmental projects and occupational affairs in relation to the management of environment. Generally, the respondents' attitudes towards some projects such as construction of houses, roads, dams, and other infrastructures; the importance of plants and animal resource management; limitation of resources; and importance of plantation in the community were enquired and well responded. The Figure 3 showed that thirty four percent (34\%) did not agree with the idea of resources are in abundance, and so, no matter how it is mismanaged, will not decline or be detrimental to the environment.

On the other hand, fifty nine percent (59\%) agreed that poor utilization of resources and mismanagement of environmental phenomenon can cause adverse effect to the human health and may lead to disasters and other problems in the ecosystem. However, only seven percent $(7 \%)$ of the respondents expressed that they neither agree nor disagree that poor utilization of resources and mismanagement of environmental phenomenon can directly or indirectly affect the human health and may lead to ecological damages. Although the people attitude towards environmental management in Ringim community is good because they agreed that, poor utilization of resources and the environment has a significant effect to the area. But small portion of the population $(7 \%)$ did not have any idea about the concept. This implies that local inhabitants in the study area need frequent awareness campaigns and strongly advise to seek for more knowledge about management of the environment and effective utilization of natural resources.

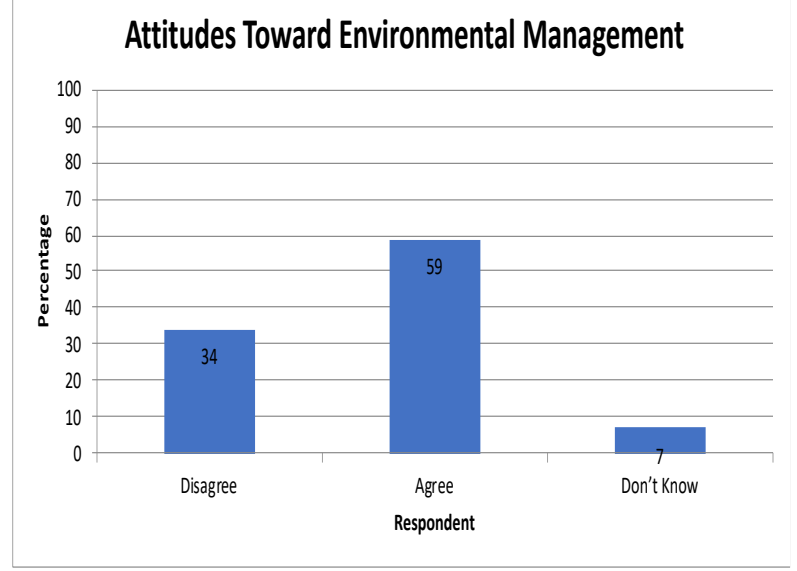

FIGURE 3: Attitudes Towards Environmental Management

\section{Waste Disposal Approaches}

Knowledge about waste management is another tool for assessing the level of environmental awareness within a particular area. This research requested various information of different processes of waste collection and disposal within the study area. Sixty six percent (66\%) of the respondents uses open disposal as their way of managing waste. Often, they parked it to the farm when the quantity increases which serve as manure since it is mostly organic waste. Enough utilization of indigenous knowledge systems enables sustainable development and sustainable use of natural resources $[10,6]$. While five percent $(5 \%)$ responded that they dump their waste in waterways. And consequently, this attitude has manifested a deleterious effect to the environment, resulting in disasters such as flooding and malaria outbreak in the communities. 
However, fourteen percent (14\%) of the respondents expressed their views based on the proximity. They used to dump their waste in the farm directly because they are very close to the farms. Some of the people (18.28\%) in the study area just burn their household waste without any proper consideration.

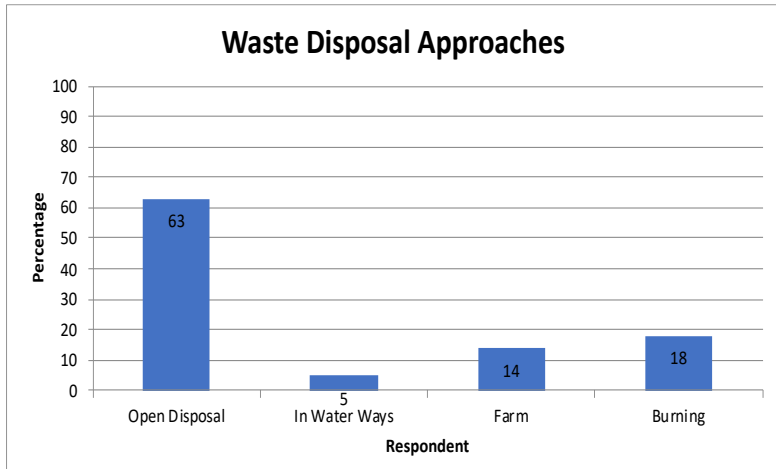

FIGURE 4 : Waste Disposal Approaches

Furthermore, open dumping is a common method of waste disposal in most of the developing countries [11]. As stated above, a greater portion of the population adopted an open dumping, and this is safer than waterways dumping or open burning. Thus, a relatively effective waste management approach investigated in this study, found to be an open disposal that is characterized with "afterward transfer" to farms prior to rainy season.

\section{Effectiveness of Indigenous Knowledge in Environmental Management}

Environmental Indigenous knowledge also called folk knowledge or knowledge passes on from one generation to another. This knowledge plays a vital role in the conservation of natural resources such as forest and trees, water, wildlife; soil management and numerous aspects of climate prediction. This knowledge helps in the effective management of immediate environment. The effectiveness of indigenous knowledge in environmental management within the study area was investigated. The respondents' view on the different methods of indigenous knowledge employed in managing their environmental challenges is connoted as Effective, Non-effective or Unsure. As illustrated in Figure 5, seventy-one percent (71\%) said that the indigenous Knowledge system used in managing the environmental resources is effective.

While twenty-eight percent (28\%) respondents stated that the level of indigenous knowledge in the management of environment is non-effective. Whereas, only one percent (1\%) of the respondents said to be unsure, which means they have no idea about the indigenous knowledge system used in the management of environment within the community. However, it is clear that this knowledge ought to be served as an alternative method of promoting development in poor rural communities of Ringim Local Government Area.

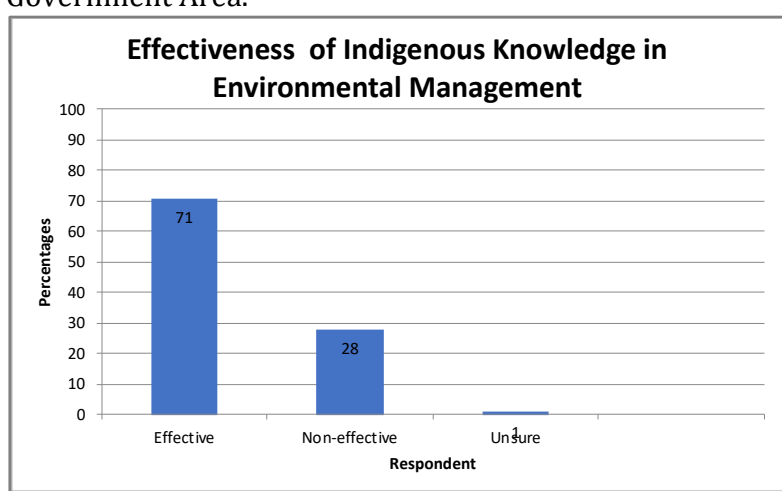

FIGURE 5 : Effectiveness of Indigenous Knowledge in Environmental Management
Thus, based on the overall data analyzed, the level of indigenous knowledge in managing the environmental challenges was very effective in the study area. This indicates that the study area utilizes local knowledge for the conservation of the immediate natural resources as well as in the management of the built environment. Although, the indigenous knowledge is developed outside the formal education system, it does not necessarily operate within formal organizations and is mainly transferred by mere verbal discourse $[12,13]$.

\section{Methods Used in Transmitting Environmental Knowledge Within the Study Area}

Basically, the channels through which the indigenous knowledge of environmental management pass within Ringim community is divided in to three main categories namely; Parents, society and school. About fifty-three percent (53\%) of the participants unanimously agreed that the knowledge of environmental management is being learnt from parents through moral lessons and practical applications. Besides, other seventeen percent $(17 \%)$ of the participants believed that the environmental knowledge is acquired and disseminated through social interactions in the society. This knowledge is basically acquired via a societal collective response to a particular environmental problem. Obviously, the local people of this study area were known to their collective responsibilities. This attitude helps them learn and understand the importance of indigenous knowledge gained through collective work and mobilization (Aikin Gayya), that is regularly taking place on the basis of monthly, quarterly, or annually. It is very important exercise through which the community members gather and participate in many environmental promotion activities, ranging from plantation of trees, clearance of drainages, clear up the litters that are openly disposed of and so on.

However, the last category that constitutes thirty percent $(30 \%)$ of the respondents is learning institution in other word schools as shown in Figure 6. In schools, the curriculum is designed in a such a way that would portray the significance of teaching the environmental knowledge. In both primary and secondary schools, many subjects such as Health Education, Social Studies, Physical Health Education (PHE), Civic Education etc. are taught to educate and train the pupils/students on how to take care of the immediate environment as well as prevention from diseases. These learning institutions tremendously help in passing environmental knowledge within the community.

Methods used in transmitting environmental Knowledge within the study area

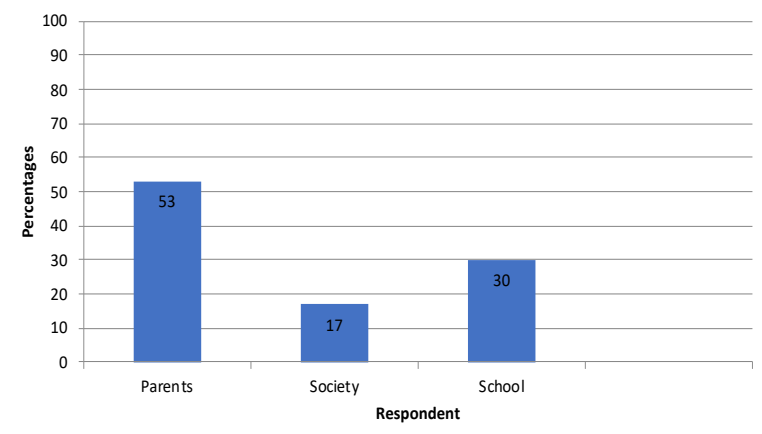

FIGURE 6 : Methods Used in Transmitting Environmental Knowledge Within the Study Area

\section{The Trend in Environmental Management}

It was discovered that, in the olden days people were responsible for managing their environment through collective actions. These actions include weekly sanitation, tree planting, construction and clearing of drainages etc. 
This study also intended to investigate the existing variation between the past and present way of managing the environment. As depicted in Figure 7, the results obtained have shown that fifty-two percent (52\%) of the respondents agreed upon that the systems did not significantly change. That is to say, the community members are still responsible for the management of their environment through collective works. Thirty-eight percent (38\%) expressed their opinions that the management of environment nowadays is mainly carried out by the government. Whereas, only ten percent $(10 \%)$ were unsure about whether there is an existing variation between present and past methods of managing the environment in the study area.

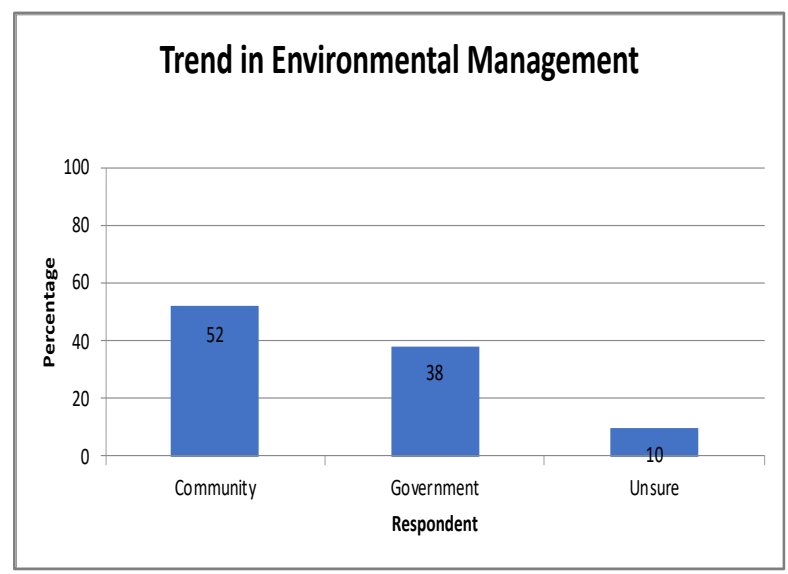

FIGURE 7 : The Trend in Environmental Management

From the Figure 7 above, the results indicated that there is little variation in the process of managing the environment and that community is still in charge of the management even though the government is actively participating.

\section{Causes of Flooding in Ringim Community}

The frequent occurrence of flooding is related to deforestation and the impact is seriously seen in developing countries [14, 15]. Figure 8 showed how a forest was being transformed to a deforested land for the purpose of agricultural activities. Flooding is one of the most pronounce environmental catastrophes in Ringim community and has over the past few years become an annual phenomenon.

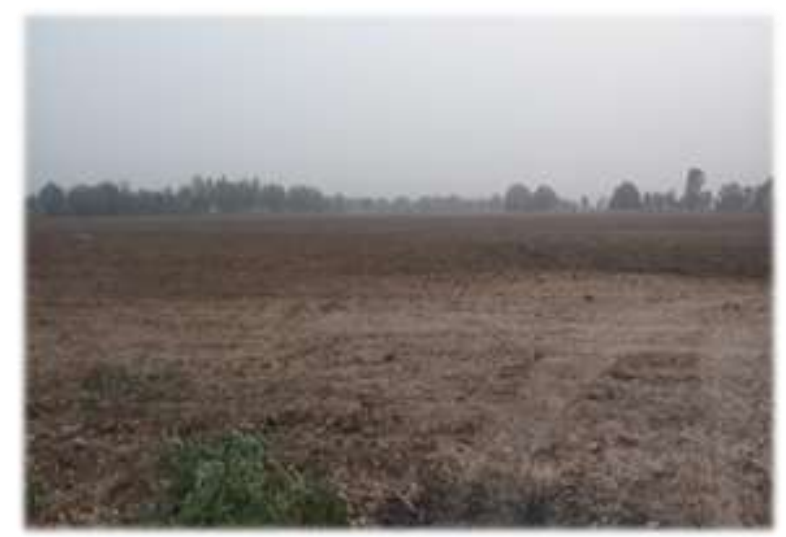

FIGURE 8 : Deforested Area for Agricultural Use

This research investigated the root causes of this disaster. A set of questions were asked on what the respondents think are the causes of flooding in the area. Only four (4\%) of the respondents blamed the attitudes of structural construction along floodplain as the main causes of flooding in the study area as shown in Figure 9.

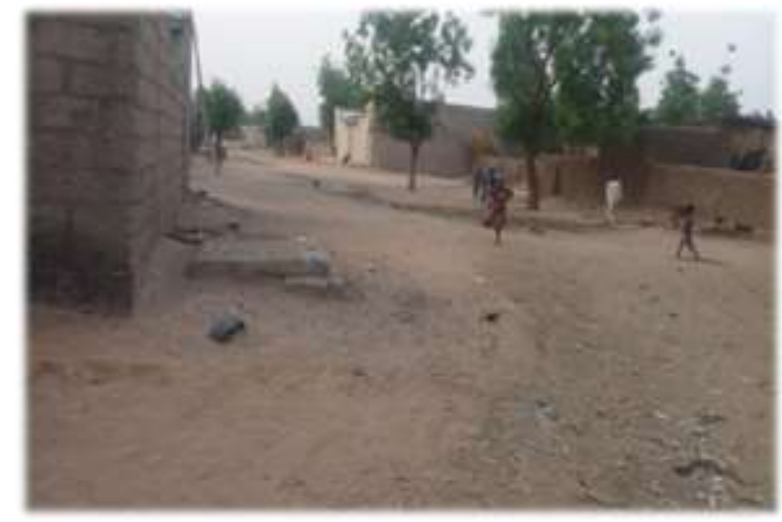

FIGURE 9 : Flood Plain Area

While more than seventy-two percent $(72.92 \%)$ stressed that poor drainage system is the major problem that paves the way for frequent flooding. However, some of the respondents $(7.29 \%)$ are of the view that topographical factors are responsible for the menace. The area is characterized by a low land and sandy soil in nature. The soil gets easily saturated and thereby leading to surface runoff and consequently over flow. Conversely, Nelson, (2011) viewed flood as a natural consequence of stream flow in a repeatedly changing environment [16].

Furthermore, some of the respondents (5.21\%) said unplanned settlements in the study area is the major cause of flooding. Meanwhile, some of the participants (10.42\%) assumed that rainfall intensity is the root cause of flooding in Ringim community. In 2010, thousands of residents of at least 25 villages in Ringim LGA of Jigawa State became homeless by the flood that followed the seasonal rainfall [17].

During the last two decades, the increasing demand for sufficient food has stimulated different anthropogenic activities [18]. Yet, flash flooding/urban flooding destroys the produce such as crop, rice paddy, fruit tree and vegetables thereby posing the risk of hunger to those engaged in subsistence farming and great loss to those engaged at a commercial scale $[19,20]$. According to Action Aid International (2006) flood hazards are natural phenomena, but damage and losses from floods are the consequence of human action.

Thus, this shows that the major cause of flooding is poor drainage network that could directly or indirectly allow the overflow of the water from the area of higher altitude to a lower when there is high rainfall and thereby causing over saturation in the soil and consequently flooding occurs.

\section{Causes of Flooding in Ringim Community}

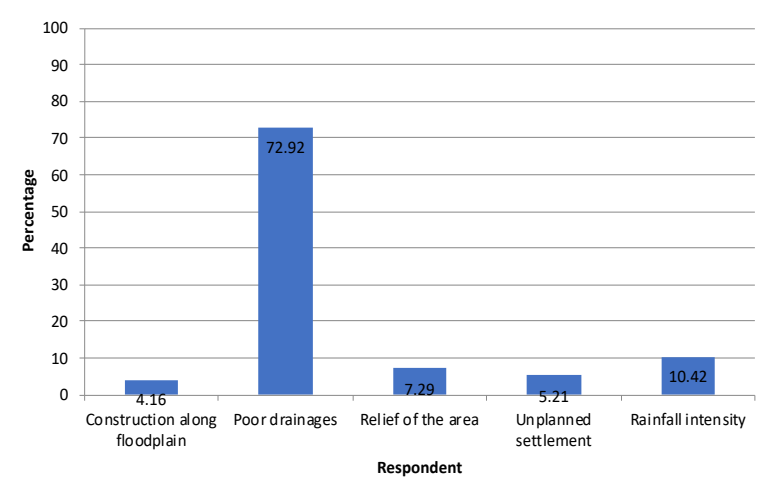

FIGURE 10 : Causes of Flooding in Ringim Community 


\section{CONCLUSION}

From the findings of this research, it can be concluded that the level of environmental awareness and indigenous knowledge in managing the environment is very effective within the study area. Also, based on the perception of the local people on environmental education and the variations that occurs as a result of modernization, their attitudes towards maintaining and management of environment, as well as natural resources found to be very effective in the study area. As the area faced with frequent flooding as a result of poor drainage network, it was also found that the local community members have their own local ways to manage and protect themselves through construction of local drainages, fortifying and repairing of buildings every year against flood, and clearing the waterways (drainages) annually in form of collective community work. The research also found that, using domestic waste as organic manure is an effective way of managing the waste in the environment.

\section{ACKNOWLEDGMENT}

The authors wish to acknowledge the Research Team of Prof. Chen Deqiang and other fellow research assistants in the college of Environment, Hohai University Nanjing, P. R. China for their immense contributions towards compiling this article.

\section{REFERENCES}

[1] Ibrahim, M., Young, A. C., Chen, D., \& Mughal, N. (2021). Potential ecological risk, in-situ phytoextraction potential of Lycopersicon esculentum, and pollution indices of selected toxic metals in Hausawan - Kaba, Kano State, Nigeria. Environmental Challenges, 4(March), 100113. https://doi.org/10.1016/j.envc.2021.100113

[2] Breemer, J. P. (1995). Local Resources Management in Africa. Chichester: John Wiley.

[3] Chiwandamira, L. (2000). Environmental Policy. Zimbabwe: Zimbabwe Open University, Harare.

[4] EPA. (2016). Enviromental Protection Agency. Retrieved December 1, 2016, from www.epa.gov: http//www.epa.gov

[5] Ibrahim, M. (2019). Air Quality Analyses for Photochemical Smog Associated with Atmospheric Aerosol Particles and Ozone Precursors Using CMAQ and CAMx Modeling Systems. International Journal of Scientific Research in Science and Technology, 224235. https://doi.org/10.32628/ijsrst196530

[6] Ali, T., Ahmad, M., \& Khalifa, H. (2019). Role of indigenous knowledge in managing floods projects. Journal of Process Management. New Technologies, 7(4), 13-23. https://doi.org/10.5937/jouproman721018

[7] National Population Commission (NPC, 2016) Jigawa State in Nigeria. retrieved on $2 / 8 / 2021$, from https://www.citypopulation.de/php/nigeriaadmin.php?adm1id=NGA018

[8] Ibrahim, M., Daniel, A. K., Kiyawa, S. A., \& Kutama, A. S. (2017). Phyto-Accumulation of Lead and Chromium in Common Edible Green-Leafy Vegetables Consumed in Dutse Metropolis, Jigawa State, Nigeria. International Journal of Chemical, Material and Environmental Research (Vol. 4, Issue 3). https://www.researchgate. net/publication/336837288_Phyto_Accumulation_of_ Lead_and_Chromium_in__Common_Edible_GreenLeafy_Vegetables_Consumed_in_Dutse_Metropolis_jig awa_State_Nigeria.
[9] Sasaki, K., Sasaki, Y., \& Fox, S. (2010). Endangered traditional beliefs in japan: Influences on snake conservation. Herpetological Conservation and Biology, 474-485.

[10] Numafo-Brempong, L., Dawoe, E., \& Ibrahim, M. (2019). Assessment of the Effect of Biochar and Leucaena Leucocephala on the Growth and Yield of Maize (Zea mays). International Journal of Scientific Research in Science and Technology, 34-45. https://doi.org/10.32628/ijsrst19641

[11] Khadija, B. U., \& Ibrahim, M. (2019). Assessment of the Pollution extent of Sulphur Dioxide (SO2) and Nitrogen Dioxide (NO2) in Ambient air within Kano Metropolis, Kano State, Nigeria. Journal of Environmental Science, Computer Science and Engineering \& Technology, 8(8), 396-404. https://doi.org/10.24214/jecet.A.8.4.39604.

[12] Guchteneire, P., Krukkert, I., \& Liebenstein, G. V. (1999). Best Practices on Indigenous knowledge. Joint Publication of the Management of Social Transformations Programme (MOST) and the Centre for International Research and Advisory Networks (CIRAN). Netherland, 20-26.

[13] Kaniki, A. M., \& Mphahlele, M. K. (2002). Indigenous knowledge for the benefit of all: Can knowledge management principles be used effectively? South African Journal of Library and Information Sciences, 68(1), 1-68.

[14] Angela, A. D., Jennifer, M., \& Ibrahim, M. (2019). Assessment of the Quality of Water from Rooftops (A Case Study of "Nkamponasi" in Tarkwa, Ghana). International Journal of Scientific and Research Publications (IJSRP), 9(5), p8941. https://doi.org/10.29322/ijsrp.9.05.2019.p8941

[15] Bello, O., Ganiyu, O., Wahab, M., Afolabi, M., Oluleye, F., Igui, S., et al. (2012). Evidence of Climate Change Impacts on Agriculture and Food Security in Nigeria. (2012). Int. J. Agric. For. 2(2):49-55. , 49-55.

[16] Nelson, S. (2011). River systems and causes of flooding. Tulane: Tulane University.

[17] Tina, A. (2010). Nigeria: Flood Devastates Jigawa Villages. Ringim: Vanguard

[18] Young, A. C., \& Ibrahim, M. (2021). Bioaccumulation of Heavy Metals in Lycopersicon Esculentum Grown with Tannery Sludge across Some Selected Farmlands in Dawakin Kudu LGA of Kano State, Nigeria. International Journal of Scientific Research in Science and Technology, 251-257. https://doi.org/10.32628/ijsrst218238

[19] Kolawole, O., Olayemi, A., \& Ajayi, K. (2011). Managing Flood in Nigerian Cities: Risk Analysis and Adaptation Options - Ilorin City as a Case Study. Archives of Applied Science Research, 17-24.

[20] Abdallah, M. S., Ibrahim, M., \& Warodi, F. A. (2017). Review on Some Plants as Bio - Pesticides. International Journal of Contemporary Research and Review.

https://doi.org/10.15520/ijcrr/2017/8/07/203 